\title{
Ceramic Injection Molding
}

\author{
Zdravko Stanimirović and Ivanka Stanimirović \\ IRITEL A.D., \\ Republic of Serbia
}

\section{Introduction}

Powder injection molding (PIM), which encompasses metal injection molding (MIM) and ceramic injection molding (CIM), is a net-shaping process which enables large scale production of complex-shaped components for use in a diverse range of industries. It combines plastic injection molding techniques and performance attributes of ceramic and metal powders. Ceramic injection molding (CIM) uses ceramic powders such as alumina, zirconia, titania, ferrite powders, etc. It was introduced in 1940's, but for the next thirty years it was of minor interest to ceramic industry. In 1970's and 1980's CIM provided cost-effective fabrication method for mass production of ceramic parts for automotive industry. Today more than 300 companies practise PIM. Most of them practise MIM technology $(>70 \%)$. Small percentage $(5 \%)$ produce metals, ceramics and carbide components and about $25 \%$ practice CIM technology. This positive tendency can be attributed to unique properties of ceramic materials. They have excellent mechanical properties and low specific weight. Also, they are suitable for applications under extreme conditions (high temperatures, corrosive atmospheres, abrasive conditions, high loads at high temperatures). This combination makes them interesting for a wide variety of applications.

The ceramic injection molding process consists of four basic steps: feedstock preparation, injection molding, debinding process and sintering (Fig. 1).When powder technologies are in question, the key step in production process is choosing the adequate ceramic powder. Specific surface area, particle size, size distribution, particle shape and purity of the powder influence properties of the feedstock. Typical particle sizes in CIM are $1-2 \mu \mathrm{m}$, but also much finer particles down to submicron or nano region are being used in advanced CIM. CIM uses a feedstock of composite granulate. A high concentration of ceramic powder is mixed with a thermoplastic binder system to form moderate viscosity feedstock - homogenous powder-binder mix that is free of agglomerates, has optimum ceramic/binder content and still maintains sufficient fluidity (Rak, 1999).

The feedstock is molded using injection molding equipment similar to that used for polymer injection molding. Injection molding involves concurrent heating and pressurization of the feedstock. It requires close monitoring in order to minimize molding defects. As a result, a green body is obtained (Fig. 2). After molding, the binder is extracted from the green body. Debinding usually takes place in two steps. Immersion is the first step. Soluble component of the binder is removed and system of pore channels develops to allow removal of the remaining component. The second step is thermal debinding and the insoluble component is being removed by thermal decomposition thus resulting in brown body (Fig. 2). 


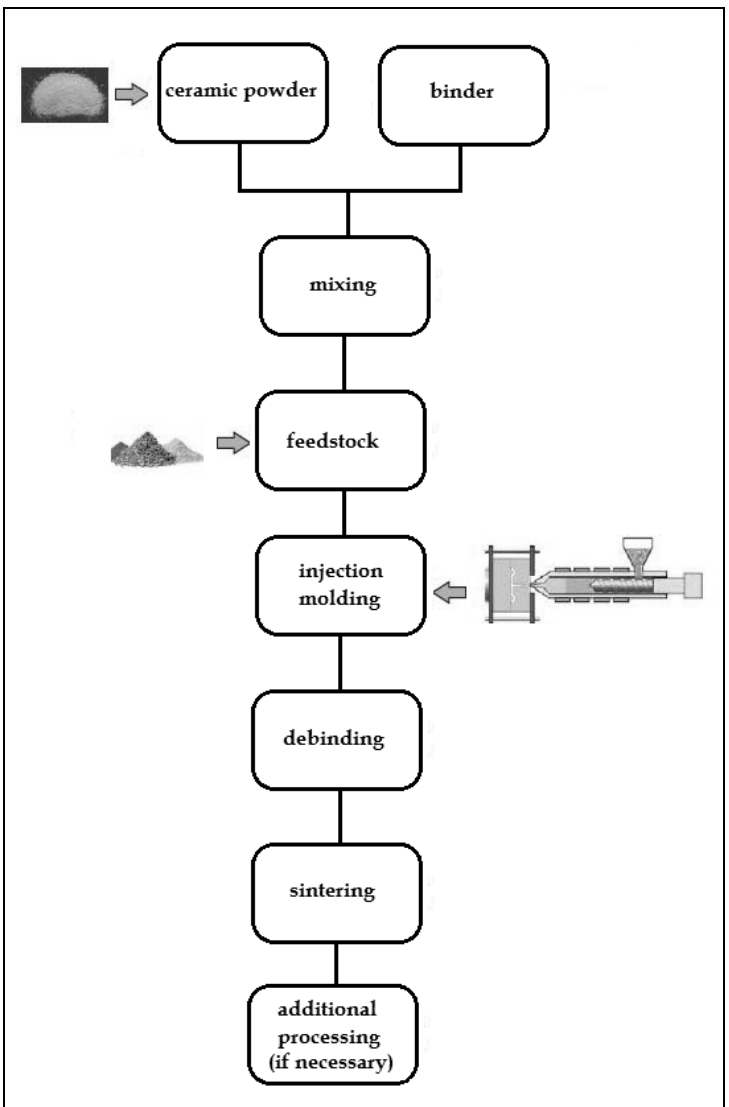

Fig. 1. The ceramic injection molding process.
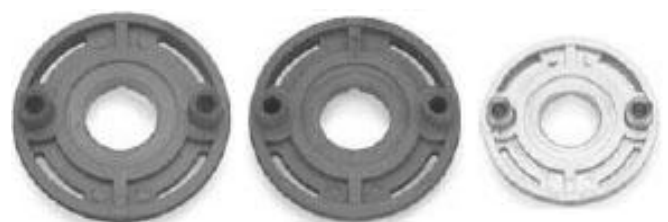

Fig. 2. CIM component: green body, brown body and sintered part, respectively.

After debinding process, the sintering process takes place. Sintering parameters depend on the type and electronic properties of the ceramic powder used and, as a result, CIM components are obtained. Quality control of ceramic components in the green, brown and sintered state is commonly carried out by visual inspection and weighting. In that way surface cracks, impurities, voids, pores, distortions, incomplete parts and skin marks can be detected. Measuring the density of sintered components is another indispensable method for characterisation of CIM parts. Additional processing after sintering is optional depending on the type of component and specific application and in standard applications is seldom required. 
In the recent past extensive international research and development activities were performed. Ferrite ceramics, piezoelectric ceramics and alumina were recognized as the most commonly used ceramic powders in production of wide range of CIM components for various applications and for that reason they are described in this chapter. Also, as an insight in future trends of CIM technology development, advanced CIM technologies are presented.

\section{Ferrite ceramics for CIM}

Ferrites are ceramic materials based on iron-oxide. They exhibit soft magnetism and therefore are being used in a variety of applications such as antennae, transformer cores, microwave waveguides, etc. There are three main types of ferrites: $\mathrm{Mn}-\mathrm{Zn}$ ferrite, Ni-Zn ferrite and $\mathrm{Mg}-\mathrm{Zn}$ ferrite. Ferrites have several advantages when compared to other materials: temperature and stability, high resistivity, wide frequency range and low loss combined with high permeability. Disadvantages are low saturation flux density and low tensile strength. Differences between soft ferrites and other magnetic materials are presented in Table 1 (Z. Stanimirović \& I. Stanimirović, 2010).

There are several techniques available to forming ferrite specimens: grinding, extrusion, pressing and injection molding. Most ferrites are commercially produced by a dry pressing process. The powder flows into a die cavity and upper and lower punches at about 10 tons per surface square inch are being applied. Since the pressing is being done in vertical direction, resulting specimen geometries are limited to simple geometric shapes. Grinding is the most economical forming technique to produce non standard ferrite cores. It requires no tooling since cores are ground from isostatically formed sintered bars. Extrusion is an ideal technique for forming long rods and bars.

\begin{tabular}{|c|c|c|c|}
\hline Parameter & Ferrites & $\begin{array}{c}\text { Magnetic } \\
\text { Alloys }\end{array}$ & $\begin{array}{c}\text { Iron } \\
\text { Powder }\end{array}$ \\
\hline $\begin{array}{l}\text { Initial permeability } \\
\text { range }\end{array}$ & $5-15000$ & $5000-300000$ & $5-150$ \\
\hline $\begin{array}{l}\text { Curie temperature } \\
\text { range }\left[{ }^{\circ} \mathrm{C}\right]\end{array}$ & $100-500$ & 500 & 600 \\
\hline Loss factor $\left[10^{-6}\right]$ & & & \\
\hline $10 \mathrm{kHz}$ & 5 & 8 & 25 \\
\hline $100 \mathrm{kHz}$ & 10 & 80 & 30 \\
\hline $160 \mathrm{kHz}$ & 25 & 4000 & 100 \\
\hline Resistivity $[\Omega \mathrm{m}]$ & $10-10^{8}$ & $10^{-5}$ & $10^{4}$ \\
\hline $\begin{array}{c}\text { Saturation flux } \\
\text { density range [mT] }\end{array}$ & $300-500$ & $800-2400$ & $1000-1200$ \\
\hline
\end{tabular}

Table 1. Differences between soft ferrites and other magnetic materials.

However, in recent years ceramic injection molding technique (Rodrigez et al., 2003; Zlatkov et al., 2008) has been applied as an alternative forming process. Injection molded ferrite parts can be produced from very simple forms to quite complex shapes. Further processing is rarely required, but if necessary, this can be achieved using conventional tools. Parts produced through this process can have very intricate shapes and tight tolerances. Injection 
molded ferrite components have properties similar to conventionally produced parts (Skolyszewska et al., 2003; Zlatkov et al., 2010).

Manganese zinc ferrite is a magnetically soft material suitable for use as magnetic cores in low frequency range $(1 \mathrm{kHz}-1 \mathrm{MHz})$. For soft ferrite magnetic core production uniaxial powder pressing technique is usually used. However, CIM as an extremely flexible technology enabled production of $\mathrm{Mn}-\mathrm{Zn}$ ferrites with characteristics comparable with commercial samples prepared by conventional methods. There are two reasons for CIM investigations of Mn-Zn ferrites: the shape complexity and the better permeability.

The starting material used for the production of $\mathrm{Mn}-\mathrm{Zn}$ ferrite samples was commercially available Mn-Zn ferrite powder shown in Fig. 3(a). Prior to injection molding, powder was processed in a conventional manner. Mn-Zn ferrite powder in combination with binder (combination of polypropylene, microcrystalline wax and stearic acid) was used for feedstock production. Feedstock contained $10.5 \%$ of binder ( $9 \%$ wax, $1 \%$ wax with lower melting temperature, $1 \%$ of stabilizer) and $68 \%$ of $\mathrm{Mn}-\mathrm{Zn}$ ceramic ferrite powder. Photograph of Mn-Zn ferrite feedstock is shown in Fig. 3(b).

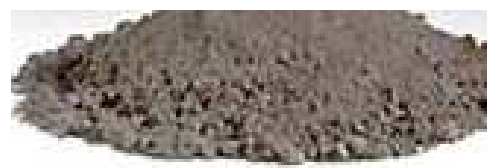

(a)

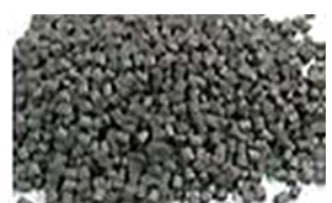

(b)

Fig. 3. Mn-Zn ferrite: powder (a) and feedstock (b).

Injection molding was performed using molds in shapes required to form ring and disc shaped specimens. The injection molding process was carried out in Battenfeld HM 250/60B4 machine and main injection molding parametres are given in Table 2. Debinding of green parts after injection molding was performed in two steps: solvent and thermal debinding. Thermal debinding was performed during initial priod of sintering $\left(150-800^{\circ} \mathrm{C}\right.$ heating period) and the green ferrite samples were sintered at $1280-1320^{\circ} \mathrm{C} / 1-4 \mathrm{~h}$ in nitrogen atmosphere.

\begin{tabular}{|l|l|}
\hline Parameter & Setup \\
\hline Injection temperature $\left({ }^{\circ} \mathrm{C}\right)$ & $120-160$ \\
\hline Mold temperature $\left({ }^{\circ} \mathrm{C}\right)$ & $30-45$ \\
\hline Injection speed $(\mathrm{ccm} / \mathrm{s})$ & $3-20$ \\
\hline Injection pressure $($ bar $)$ & $300-800$ \\
\hline Cooling time $(\mathrm{s})$ & 10 \\
\hline Sample ejection pressure (bar) & $20-40$ \\
\hline
\end{tabular}

Table 2. Main injection molding parameters.

Photographs and dimensions of injection molded ring and disc shaped CIM Mn-Zn specimens are given in Fig. 4 and Fig. 5. The main properties of injection molded sintered Mn-Zn ferrite ring shaped specimens are given in Table 3 and the comparative properties of injection molded sintered $\mathrm{Mn}$ - Zn ferrite ring and disc shaped specimens are given in Table 4. 

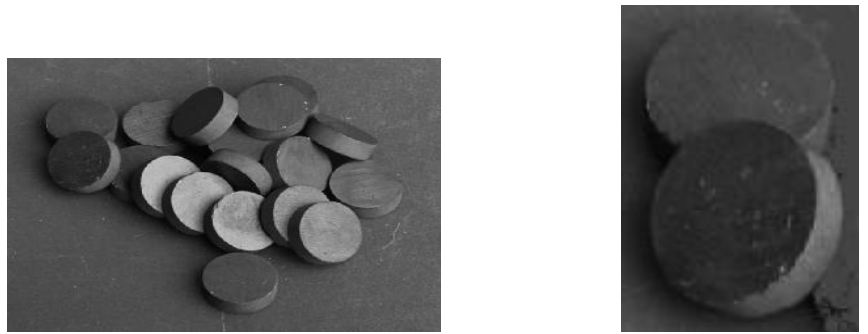

Fig. 4. Disc shaped CIM Mn-Zn ferrite samples (diameter $d=16 \mathrm{~mm}$, thickness $t=5 \mathrm{~mm}$ ).
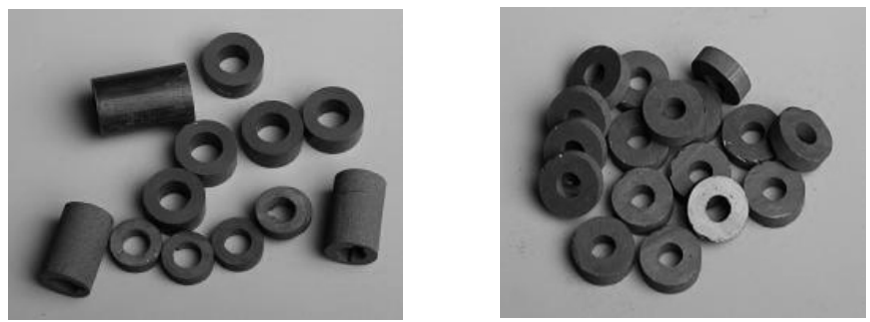

Fig. 5. Ring shaped CIM Mn-Zn ferrite samples (outer diameter $d_{o}=15 \mathrm{~mm}$, inner diameter $\mathrm{d}_{\mathrm{i}}=6 \mathrm{~mm}$, thickness $\left.\mathrm{t}=5 \mathrm{~mm}\right)$.

\begin{tabular}{|c|c|c|c|c|c|c|}
\hline $\begin{array}{c}\mathrm{T}_{\text {sint }} / \mathrm{t} \\
{\left[{ }^{\circ} \mathrm{C} / \mathrm{h}\right]}\end{array}$ & $\begin{array}{c}\text { Grain size } \\
{[\mu \mathrm{m}]}\end{array}$ & $\begin{array}{c}\text { Relative density } \\
{[\% \mathrm{TD}]}\end{array}$ & \multicolumn{2}{|c|}{ Initial relative permeability } & \multicolumn{2}{c|}{$\begin{array}{c}\text { Loss factor } \\
{[10-6]}\end{array}$} \\
\hline $1320 / 2$ & 5.83 & 89.2 & 1518 & 1305 & 13.21 & 13.9 \\
\hline $1320 / 2$ & 4.80 & - & 1238 & 1360 & 17.43 & 11.71 \\
\hline $1320 / 4$ & 7.71 & - & 1463 & 1463 & 23.52 & 21.60 \\
\hline $1280 / 2$ & 4.20 & 87.1 & 922.5 & 922.5 & 24.15 & 23.33 \\
\hline $1250 / 4$ & 4.50 & 90.4 & 717.7 & - & 37.18 & - \\
\hline $1320 / 2$ & 4.33 & 90.1 & 1609 & 1456 & 9.0 & 9.18 \\
\hline $1320 / 2$ & n.a. & 85.1 & 733.4 & 716.3 & 50.94 & 42.06 \\
\hline
\end{tabular}

Table 3. The main properties of injection molded sintered ring shaped Mn- $\mathrm{Zn}$ ferrite specimens.

\begin{tabular}{|c|c|c|}
\hline & Ring shaped specimens & Disc shaped specimens \\
\hline Initial relative permeability & $750 \pm 25 \%$ & $900 \pm 25 \%$ \\
\hline Operating frequency range [MHz] & $0.1-1$ & $0,01-0,5$ \\
\hline Relative loss factor & $8 \cdot 10^{-6}-30 \cdot 10^{-6}$ & $5 \cdot 10^{-6}-25 \cdot 10^{-6}$ \\
\hline Magnetic Induction [mT] & 390 & 390 \\
\hline
\end{tabular}

Table 4. Comparative properties of injection molded sintered Mn-Zn ferrite ring and disc shaped specimens.

Experimental work demonstrated that $\mathrm{Mn}-\mathrm{Zn}$ ferrite ceramics can be prepared using injection molding technique but the process is not trivial. For example, a special attention must be paid to initial filling of the mold. Due to uneven shrinkage rate during 
solidification, creation of stresses within the body of the sample may occur resulting in nucleation of voids or cracks. Also, if air pockets remain within the body of the specimen this may lead to poor properties of the realized component.

Problems may also occur during the burn out of the binder. Burn-out can be performed in air but this may cause excessive specimen shrinkage and surface layer exfoliation due to oxidative reaction. For that reason, nitrogen atmosphere was used. Sintering and densification of the specimen during sintering is a key factor that determines magnetic properties of the sample. Highest temperature used $\left(1320^{\circ} \mathrm{C}\right)$ yielded the highest sample densities and as illustration SEM microstructure of CIM Mn-Zn ring shaped ferrite specimen sintered at $1320^{\circ} \mathrm{C} / 2 \mathrm{~h}$ is shown in Fig. 6 .

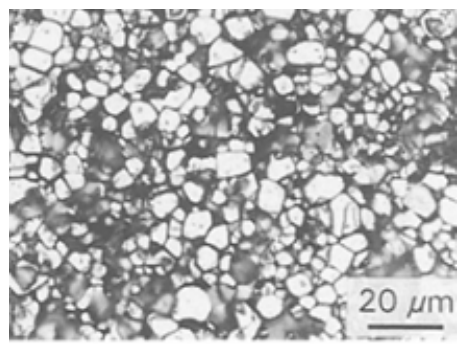

Fig. 6. SEM microstructure of CIM Mn-Zn ring shaped ferrite specimen sintered at $1320^{\circ} \mathrm{C} / 2 \mathrm{~h}$.

The grain sizes of injection molded specimens are usually smaller than grain sizes of conventionally produced $\mathrm{Mn}-\mathrm{Zn}$ ferrites. Injection molding process leads to similar specimen densities when compared to conventional methods but grain sizes are up to $50 \%$ smaller. Increase of the sintering time from $2 \mathrm{~h}$ to $4 \mathrm{~h}$ results in grain growth normally expected for Mn-Zn samples. Smaller grain sizes lead to more grain boundaries and therefore more pinning centers resulting in lower permeability. Grain growth during prolonged sintering cycle leads to greater densities and increased permeability but at temperatures higher than $1180^{\circ} \mathrm{C}$ (Pigram \& Freer, 1994) zinc volatilization occurs leading to zinc loss. For that reason, temperature of $1150^{\circ} \mathrm{C}$ (Pigram \& Freer, 1994) is recommended for adequate grain growth without zinc volatilization. Therefore, further work to optimize the processing conditions is desirable. The goal is to increase the grain size and initial permeability of realized specimens.

Experimental work on $\mathrm{Mn}-\mathrm{Zn}$ ferrite has shown that ferrite ceramics can be prepared using injection molding technique although the process is not trivial and optimization of both tools and processing conditions is essential. Mn-Zn sintering obtained by CIM technology is sensitive process compared to the conventional pressing technology, but the obtained results are satisfactory. Realized $\mathrm{Mn}-\mathrm{Zn}$ ferrite specimens have high green-state strength, ideal for production of delicate and complex shapes. Also, specimens exhibit satisfactory structural integrity and magnetic properties, as well as densities similar to conventionally produced material.

\section{Piezoelectric ceramics for CIM}

Piezoelectric ceramics is one of the functional materials which have unique electrical properties with broadening range of applications. Lead zirconate titanate $\left(\mathrm{PbZrTiO}_{3}\right)$ and 
barium titanate $\left(\mathrm{BaTiO}_{3}\right)$ are ceramic materials that have found widespread use - especially lead zirconate titanate that is being widely used in sensors, transducers, microactuators, multilayer capacitors and micro-electromechanical systems (MEMS). These materials are known for their superior piezoelectric and ferroelectric properties. When a mechanical force is applied, piezoelectric materials generate electrical voltage. Conversely, when an electric field is applied, these materials induce mechanical stress or strains. These effects are known as direct piezoelectric effect and converse piezoelectric effect, respectively.

Conventional powder metallurgy method is a commonly used method to produce piezoelectric materials. It starts with powder preparation. The powder is pressed to required shapes and size, and green shapes are processed into mechanically strong and dense ceramics. Machining process is being used for achieving desired shapes of the components. Elecroding and poling are the final sterps of the process. When complex shapes are in question, cutting and machining of piezoelectric ceramics are time consuming. There are also cost considerations because of the cost of the die and the waste material.

The most of the published papers have dealt with fabrication and electrical properties of piezoelectric ceramics produced using conventional powder metallurgy method (Fig. 7). However, a little work has been carried out on the fabrication and characterisation of piezoelectric ceramics prepared by ceramic powder injection molding method (CIM) (Luo et al., 2006; Wang et al., 1999, Zlatkov et al., 2008). In order to synthesise piezoelectric ceramics

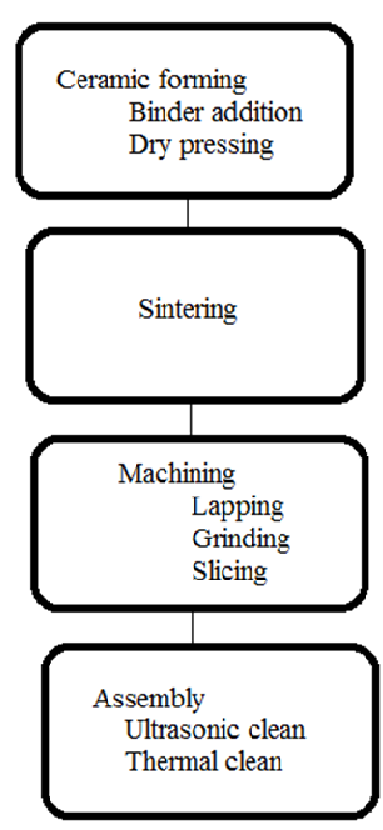

Conventional method

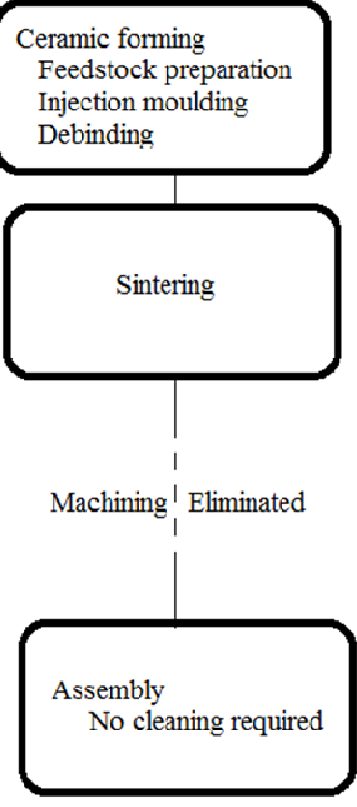

CIM method

Fig. 7. Piezoelectric ceramics production: conventional powder metallurgy method vs. CIM method (I. Stanimirović \& Z. Stanimirović, 2010). 
using CIM process, four basic steps should be performed: feedstock preparation, ceramic injection molding, debinding and sintering. Components produced by CIM are expected to have more complex shapes and more homogeneous microstructure than components produced by conventional metallurgy method. Also, reduced machining and recycling use of feedstock are significantly reducing fabrication costs.

In order to explore the feasibility to synthesise piezoelectric ceramics by CIM, two series of test samples were realized (I. Stanimirović \& Z. Stanimirović, 2010). Commercially available $\mathrm{BaTiO}_{3}$ and $\mathrm{PbZrTiO}_{3}$ powders were used. Basic properties of used powders are given in Table 5. Also, photographs of $\mathrm{BaTiO}_{3}$ and $\mathrm{PbZrTiO}_{3}$ powders are given in Fig. 8, as well as the micrograph of $\mathrm{PbZrTiO}_{3}$ powder particles Fig. 9(a).

\begin{tabular}{|l|c|c|}
\hline Ceramic powder: & $\mathrm{BaTiO}_{3}$ & $\mathrm{PbZrTiO}_{3}$ \\
\hline Density $\left[\mathrm{g} / \mathrm{cm}^{3}\right]$ & 6,2 & 7,8 \\
\hline Dielectric constant $\varepsilon_{33} / \varepsilon_{0}$ & 1700 & 2200 \\
\hline Isolation resistance $[\Omega \mathrm{m}]$ & 1011 & $10^{11}$ \\
\hline $\begin{array}{l}\text { Electromechanical coupling } \\
\text { coefficient } k_{33}\end{array}$ & 0,50 & 0,69 \\
\hline $\begin{array}{l}\text { Piezoelectric } \\
\text { coefficient } \mathrm{d}_{33}[\mathrm{C} / \mathrm{N}]\end{array}$ & $120 \cdot 10^{-12}$ & $450 \cdot 10-12$ \\
\hline Curie temperature $\mathrm{T}_{\mathrm{C}}\left[{ }^{\circ} \mathrm{C}\right]$ & 118 & 350 \\
\hline Specific surface area $\left[\mathrm{m}^{2} / \mathrm{g}\right]$ & 2,6 & 2,7 \\
\hline
\end{tabular}

Table 5. Basic properties of $\mathrm{BaTiO}_{3}$ and $\mathrm{PbZrTiO}_{3}$ powders.

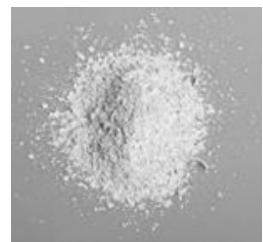

(a)

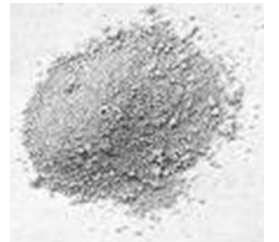

(b)

Fig. 8. $\mathrm{BaTiO}_{3}$ powder (a) and $\mathrm{PbZrTiO}_{3}$ powder (b).

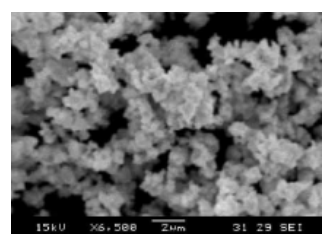

(a)

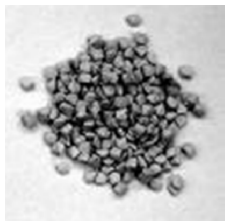

(b)

Fig. 9. Scanning electron micrograph of $\mathrm{PbZrTiO}_{3}$ powder particles (a) and $\mathrm{PbZrTiO}_{3}$ feedstock (b).

These starting materials in combination with binder were used for feedstock production. Each feedstock contained $10.5 \%$ of binder $(9 \%$ wax, $1 \%$ wax with lower melting temperature, $1 \%$ of stabilizer). Photograph of $\mathrm{PbZrTiO}_{3}$ feedstock is shown in Fig. 9 (b). 
The feedstock was then heated to a sufficient temperature - such that it melted and injected into a mold cavity where it cooled and formed desired shape. The injection molding process was carried out in Battenfeld HM 250/60-B4 machine and the main parameters of injection molding corresponded to ones listed in Table 2. Dimensions of green bodies were $20 \mathrm{~mm} \times 10 \mathrm{~mm} \times 2 \mathrm{~mm}$. In accordance with the binder system, debinding procedure was performed. A two-stage debinding technique was applied. The solvent debinding stage was followed by thermal debinding stage. The main debinding parameters are given in Table 6 . The slow heating rate prevented defects such as micro-cracks, slumping and blistering of the parts to be induced during debinding process.

\begin{tabular}{|c|c|}
\hline In a water bath: & $24 \mathrm{~h}$ in a destilled water \\
\hline \multirow{4}{*}{$\begin{array}{c}\text { In chamber drying } \\
\text { device with fan: }\end{array}$} & $4 \mathrm{~h}$ at $80^{\circ} \mathrm{C}$ \\
\cline { 2 - 2 } & $80^{\circ} \mathrm{C}-145^{\circ} \mathrm{C}$, rising degree $\left[20^{\circ} \mathrm{C} / \mathrm{h}\right]$ \\
\cline { 2 - 2 } & $145^{\circ} \mathrm{C}-155^{\circ} \mathrm{C}$, rising degree $\left[0.5^{\circ} \mathrm{C} / \mathrm{h}\right]$ \\
\cline { 2 - 2 } & $155^{\circ} \mathrm{C}-160^{\circ} \mathrm{C}$, rising degree $\left[0.2^{\circ} \mathrm{C} / \mathrm{h}\right]$ \\
\cline { 2 - 2 } & $160^{\circ} \mathrm{C}-170^{\circ} \mathrm{C}$, rising degree $\left[2-5^{\circ} \mathrm{C} / \mathrm{h}\right]$ \\
\cline { 2 - 2 } & $170^{\circ} \mathrm{C}-220^{\circ} \mathrm{C}$, rising degree $\left[10^{\circ} \mathrm{C} / \mathrm{h}\right]$ \\
\cline { 2 - 2 } & $220^{\circ} \mathrm{C}-300^{\circ} \mathrm{C}$, rising degree $\left[20^{\circ} \mathrm{C} / \mathrm{h}\right]$ \\
\cline { 2 - 2 } & At $300^{\circ} \mathrm{C}$ holding time $2 \mathrm{~h}$ \\
\hline
\end{tabular}

Table 6. Two-stage debinding procedure.

After the debinding process, the debinded parts were sintered in an air atmosphere. In order to minimize lead loss from $\mathrm{PbZrTiO}_{3}$ bodies that occur at about $800^{\circ} \mathrm{C}$, these samples were sintered in presence of a lead source. Basic information about the sintering process is given in Table 7.

\begin{tabular}{|c|c|}
\hline Butch kiln & ELEKTRON 1500 \\
\hline Sagger & Alumina $98 \%$ \\
\hline Sagger cover & Alumina $98 \%$ \\
\hline Bottom plates & $\mathrm{ZrO}_{2}$ \\
\hline $\begin{array}{l}\text { Setting and } \\
\text { safety powder }\end{array}$ & $\mathrm{ZrO}_{2}$ and $\mathrm{Pb}_{3} \mathrm{O}_{4}$ \\
\hline Manual filling & 20 psc. green bodies/sagger \\
\hline \multirow{5}{*}{$\begin{array}{l}\text { Sintering } \\
\text { conditions }\end{array}$} & Air atmosphere \\
\hline & $21^{\circ} \mathrm{C}-600^{\circ} \mathrm{C}$, rising degree $\left[100^{\circ} \mathrm{C} / \mathrm{h}\right]$ \\
\hline & $\begin{array}{c}\mathrm{PbZrTiO}_{3}: 600^{\circ} \mathrm{C}-1250^{\circ} \mathrm{C} \text {, } \\
\mathrm{BaTiO}_{3}: 600^{\circ} \mathrm{C}-1260^{\circ} \mathrm{C}, \\
\text { rising degree }\left[150^{\circ} \mathrm{C} / \mathrm{h}\right]\end{array}$ \\
\hline & $\begin{array}{c}\mathrm{PbZrTiO}_{3}: 1250{ }^{\circ} \mathrm{C}, \mathrm{BaTiO}_{3}: 1260^{\circ} \mathrm{C}, \\
\text { holding time } 2 \mathrm{~h}\end{array}$ \\
\hline & Cooling $1250^{\circ} \mathrm{C} / 1260^{\circ} \mathrm{C}-21^{\circ} \mathrm{C}$ : Natural \\
\hline
\end{tabular}

Table 7. Sintering process.

Dimensions of sintered samples were $16.67 \mathrm{~mm} \times 8.43 \mathrm{~mm} \times 1.52 \mathrm{~mm}\left(\mathrm{PbZrTiO}_{3}\right.$ samples $)$ and $16.6 \mathrm{~mm} \times 8.42 \mathrm{~mm} \times 1.5 \mathrm{~mm}\left(\mathrm{BaTiO}_{3}\right.$ samples$)$. After the sintering process, $\mathrm{PbZrTiO}_{3}$ samples 
were silver plated using screen printing process and fired in an air atmosphere at $750^{\circ} \mathrm{C} / 10 \mathrm{~min}$. All samples were then polarized and functional and electrical measurements were performed (Table 8). Photographs of $\mathrm{CIM} \mathrm{PbZrTiO}_{3}$ and $\mathrm{BaTiO}_{3}$ samples are given in Fig. 10 and Fig. 11.

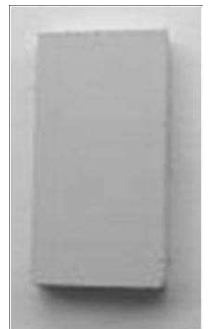

(a)

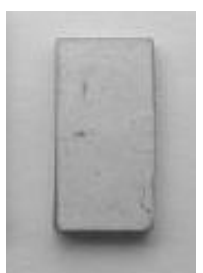

(b)

Fig. 10. CIM PbZrTiO 3 samples: green (a) and sintered and silver plated (b).

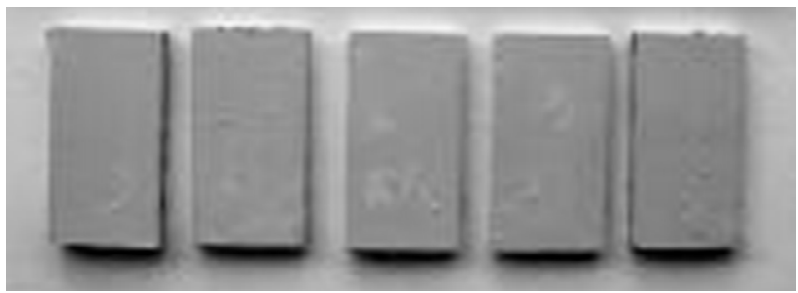

Fig. 11. CIM BaTiO 3 samples.

\begin{tabular}{|l|c|c|}
\hline & $\mathrm{BaTiO}_{3}$ & $\mathrm{PbZrTiO}_{3}$ \\
\hline Dielectric constant $\varepsilon_{33} / \varepsilon_{0}$ & $2000 \pm 30$ & $1700 \pm 30$ \\
\hline Loss tangent tg $\delta_{\max }$ & 0.02 & 0.02 \\
\hline $\begin{array}{l}\text { Electromechanical coupling } \\
\text { coefficient } k_{33}\end{array}$ & 0.65 & 0.50 \\
\hline $\begin{array}{l}\text { Piezoelectric } \\
\text { coefficient } \mathrm{d}_{33}[\mathrm{C} / \mathrm{N}]\end{array}$ & $550 \pm 50 \cdot 10^{-12}$ & $120 \pm 50 \cdot 10^{-12}$ \\
\hline
\end{tabular}

Table 8. Basic properties of $\mathrm{BaTiO}_{3}$ and $\mathrm{PbZrTiO}_{3}$ samples.

In order to evaluate feasibility of producing piezoelectric ceramics by conventional metallurgy method and CIM, we compared results for $\mathrm{CIM} \mathrm{PbZrTiO}_{3}$ samples obtained from our study (Table 9) with those found in literature (Gu et al., 2008). Table 9 lists dielectric constants, loss tangents, electromechanical coupling coefficients and piezoelectric coefficients for samples obtained by those two methods.

The dielectric constant is a measure of charge stored on an electrode material brought to a given voltage. It strongly depends on sintering temperature for both CIM and conventional metallurgy method. When conventional method is concerned, dielectric constant increases with sintering temperature due to the increase in $\mathrm{PbZrTiO}_{3}$ grains. For $\mathrm{CIM}$ samples, dielectric constant increases with sintering temperature to $1250^{\circ} \mathrm{C}$ and then decreases with sintering temperature because of the deceased density due to lead loss. Therefore observed difference in 
dielectric constants obtained by two methods can be attributed to microstructure development and change in grain size with variation of sintering temperature.

\begin{tabular}{|l|c|c|}
\hline & CIM method & $\begin{array}{l}\text { Conventional powder } \\
\text { metallurgy method } \\
\text { (Gu et al., 2008) }\end{array}$ \\
\hline Dielectric constant $\varepsilon_{33} / \varepsilon_{0}$ & $1700 \pm 30$ & 1210 \\
\hline Loss tangent tg $\delta_{\max }$ & 0.02 & 1.0 \\
\hline $\begin{array}{l}\text { Electromechanical } \\
\text { coupling coefficient } \mathrm{k}_{33}\end{array}$ & 0.50 & 0.27 \\
\hline $\begin{array}{l}\text { Piezoelectric } \\
\text { coefficient } \\
\mathrm{d}_{33}\left[10^{-12} \mathrm{C} / \mathrm{N}\right]\end{array}$ & $120 \pm 50$ & 97 \\
\hline
\end{tabular}

Table 9. Comparative properties of $\mathrm{PbZrTiO}_{3}$ samples.

Electromechanical coupling coefficient and piezoelectric coefficient are slightly lower than those from reference, while the loss tangent is higher for samples realized using CIM method than for samples obtained by conventional metallurgy method. They strongly depend on processing parameters, especially sintering temperatures, and by further adjustment of various processing parameters, CIM technology can provide $\mathrm{PbZrTiO}_{3}$ components with application-specific properties similar to those provided by conventionally produced components.

Obtained results have shown that piezoelectric ceramics can be successfully produced by CIM method. Sintering temperature was found to play important role in physical, mechanical and electrical properties since it affects sample density and porosity. The obtained sample properties were comparable to those found in literature. It is important to note that in comparison with conventional powder metallurgy, CIM samples have more homogenous microstructure and production costs are reduced by reducing machining and recycling use of feedstock. Further research should be focused on processing conditions and their influence on the properties of final sintered parts, assuring satisfactory low-cost alternative for the production of piezoelectric ceramics with application specific properties.

\section{Alumina for CIM}

Aluminium oxide $\left(\mathrm{Al}_{2} \mathrm{O}_{3}\right)$ is ceramics with high mechanical hardness, high electrical resistivity and thermal conductivity. It has good strength and stiffness, good wear and corrosion resistance, good thermal stability, low dielectric constant and loss tangent, low thermal expansion, low weight, etc. It is suitable for technical ceramic, electronic and medical products, etc. CIM alumina exhibits properties close to pressed and sintered samples (Hwang \& Hsieh, 2005; Hausnerova et al., 2011; Krauss et al., 2005). The most common material that is being used for feedstock preparation is $\mathrm{Al}_{2} \mathrm{O}_{3}$ powder with $99.7 \%$ purity (Wei et al., 2000). Properties and scanning electron micrograph of $99.7 \%$ alumina powder are given in Table 10 and Fig. 12.

Multicomponent binder commonly used in feedstock preparation is 30wt \% polypropilene, $65 \mathrm{wt} \%$ paraffin wax and $5 \mathrm{wt} \%$ stearic acid. After injection molding procedure, samples are being subjected to a debinding process (Table 11). After the debinding procedure, all 
samples should be inspected to ensure that all surfaces are free from visual defect. CIM alumina samples are then sintered in air at temperatures $>1550^{\circ} \mathrm{C}$.

\begin{tabular}{|c|c|}
\hline Material & $\mathrm{Al}_{2} \mathrm{O}_{3} 99.7 \%$ \\
\hline \multicolumn{2}{|l|}{ Typical composition } \\
\hline $\mathrm{Na}_{2} \mathrm{O}(0.05 \%)$ & 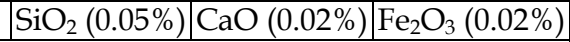 \\
\hline \multicolumn{2}{|c|}{ Typical properties of sintered parts } \\
\hline Particle size, $\mathrm{d}_{50}$ & $0.4-0.6 \mu \mathrm{m}$ \\
\hline Theoretical density & $3.85 \mathrm{~g} / \mathrm{cm}^{3}$ \\
\hline Density & $96.7 \%$ \\
\hline Purity & $99.7 \%$ \\
\hline Specific surface area & $9.0 \mathrm{~m}^{2} / \mathrm{g}$ \\
\hline
\end{tabular}

Table 10. Properties of $\mathrm{Al}_{2} \mathrm{O}_{3}$ powder.

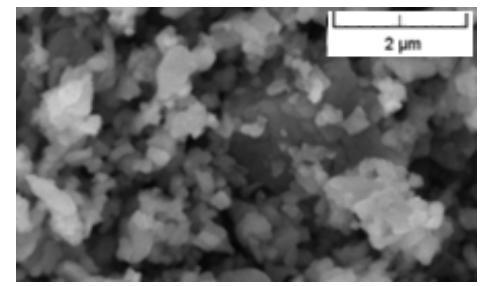

Fig. 12. Scanning electron micrograph of alumina powder.

\begin{tabular}{|c|c|c|}
\hline Immersion: & heptane, $3 \mathrm{~h}$ at $60^{\circ} \mathrm{C}$ \\
\hline \multicolumn{2}{|l|}{ Thermal debinding: } \\
\hline Ramping rate $\left({ }^{\circ} \mathrm{C} / \mathrm{min}\right)$ & Isothermal temperature $\left({ }^{\circ} \mathrm{C}\right)$ & holding time $(\mathrm{h})$ \\
\hline 2 & 200 & 0.3 \\
\hline 2 & 250 & 2.0 \\
\hline 5 & 450 & 0 \\
\hline 10 & 1000 & 0.5 \\
\hline Cooling & - & - \\
\hline
\end{tabular}

Table 11. Typical debinding procedure for CIM alumina samples.

CIM alumina is the most widely used injection molded ceramic material. CIM alumina components (Fig. 13) have high surface finish quality even with extremely complex geometries. They have high hardness end mechanical strength, high wear and corrosion stability and good electrical insulation. CIM alumina components are also dimensionally stable and able to withstand high working temperatures. Since they combine good mechanical properties with low specific weight, CIM alumina components are being used in engineering (sensor covers, sensor tubes, micro electrodes for ultrasonic welding, etc.), textile industry (textile thread guides, wire guides, etc.), medical and dental applications (orthodontic brackets, dental implants, prosthetic replacements, etc.), watches (precision watch gears), metallurgy (ceramic casting cores), automotive components (valve components), electrical components (microwave dielectric components), office equipment (inkjet printheads), etc. Recent research activities proved that CIM alumina has a great potential because nowadays it is a commonly used material in both micro-CIM and 2C-CIM technology - advanced CIM technologies. 
Fig. 13. $\mathrm{CIM} \mathrm{Al}_{2} \mathrm{O}_{3}$ sample.

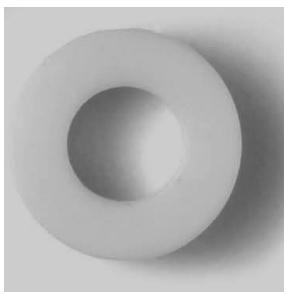

\section{Advanced CIM technologies}

Mass produced micro-parts are mainly being produced from ceramic materials which are readily available in submicron sizes because fine ceramic powders are easier to handle in comparison with metallic materials which are often pyrophoric in submicron sizes and for that reason difficult to handle. Micro-CIM, as an expanding technology for mass-production of micro-parts, emerged as a combination of plastic micro-injection molding technology and ceramic injection molding technology. It shares the same basic steps as the conventional CIM-technology, but it also exhibits special characteristics due to micro-size of the components (Liu et al., 2011; Piotter et al., 2003, 2010; Zauner, 2006). Micro-CIM parts can be formed using variety of ceramic materials such as $\mathrm{ZrO}_{2}, \mathrm{Al}_{2} \mathrm{O}_{3}, \mathrm{Si}_{3} \mathrm{~N}_{4}$, AlN and PZT and their main application fields are microsystem technology, microfluidics, biosensors, MEMS, medical technology, etc. (Fig. 14).

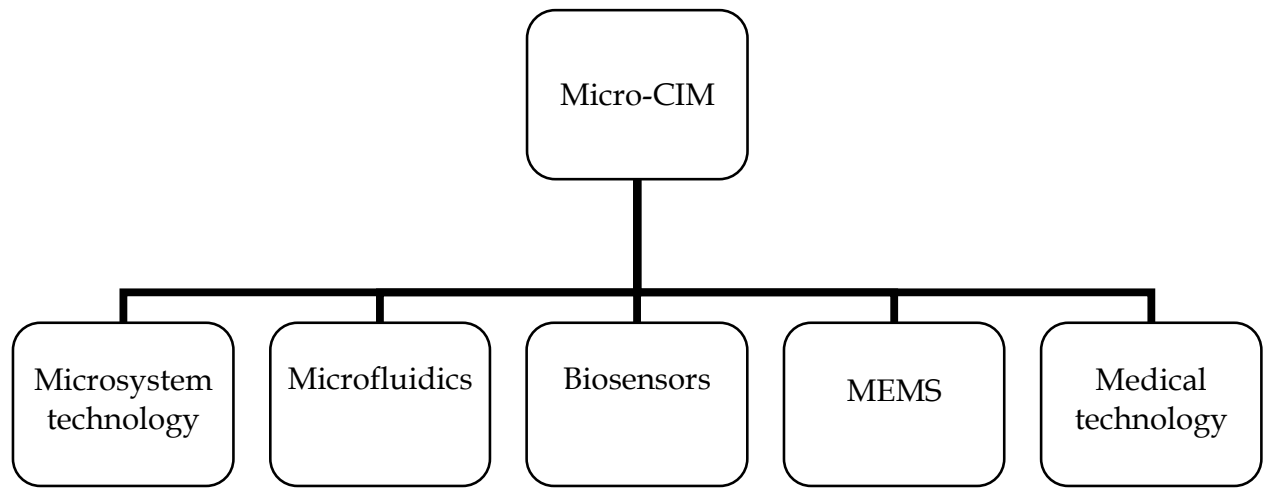

Fig. 14. Micro-CIM applications.

The increasing expansion of microsystem technology (MST) induced a great demand for the production of high-quality low-cost 3D micro-sized components such as micro-sensors, micro-reactors and micro-parts. The current microsystem production technologies (microcutting, laser ablation, LIGA, etc.) due to their high cost, low efficiency and limited materials are being replaced by micro-CIM technology that, as a miniaturized variant of CIMtechnology, offers greater shape complexities, applicability to a wide range of materials and good mechanical properties. Micromechanical components made by micro-CIM are used to 
replace plastic parts and they especially benefit from ceramic material properties like corrosion resistance and high-temperature performance. Microfluidics and microreaction technology, biomedical industry and other growing markets give excellent opportunities for microparts. For some applications, such as reactions of highly corrosive media or high temperature gas phase reactions, micro-CIM components are of greatest interest due to their hardness and high chemical and thermal resistance. Also, there is a strong request for biocompatible materials such as ceramics and reliable technologies to produce complex shaped medical components.

The raw materials for micro-CIM technology are fine ceramic powders that allow production of micro-components with feature sizes down to $5 \mu \mathrm{m}$. The powder has to be homogeneous and in order to obtain a fairly isotropic behavior the grain size of the sintered part should be at least one order of magnitude smaller than the minimum internal dimensions of the micro-part. From the aspect of surface quality, the best results can be achieved by using ceramic powders with mean particle diameter of $0.5 \mu \mathrm{m}$ or smaller. The viscosity of the melt should be sufficiently low to fill even the smallest structural details down to submicron range. For that reason, the molding tool should be heated near the melting point of the feedstock prior to injection into the tool. Because of the micro-part fragility highly precise tool movements are required. In order to control acceleration or slowing down of the injection molding process, ramps are being used. Micro injection molding machines use position regulated screws for that purpose. Also, micro components are considerably more difficult to handle from macroscopic components. They tend to stick to handling systems instead of dropping when electrostatic forces exceed gravitation force.

As an example of micro-CIM component, schematic presentation of zirconia $\left(\mathrm{ZrO}_{2}\right)$ micro gearwheel is shown in Fig. 15. It is a typical example of micro component for micromechanical applications. Micro gearwheels are demanding microstructures. Successful replication of structural details requires establishment of critical dimensions and determination of various physical properties such as densities, surface qualities, etc. However, geometry of the part is not a key factor when performances of the component are in question. The key factor is the surface quality of micro-CIM component. For production of $\mathrm{ZrO}_{2}$ micro gearwheels high quality mold inserts are required. Cavities have to be scaled up by the certain percentage because of the shrinkage and have to be micro milled employing smallest mill cutters. Minimum edge radius within the mold and cutting depth affect the tooth shape. Besides restrictions related to manufacturing adequate mold inserts for micro gearwheel realization, there are also restrictions of molding as well as restrictions of sintering. Beside typical limits for ejection molding (aspect ratio), there are limitations related to design of the gate system. Demolding is also a challenge because the ejector pins have to be arranged very accurately due to the lack of space. When sintering process is in question, the shrinking, temperature and other process variables must be particularly taken into account. There are different temperatures in different places in the oven resulting in variable shrinking factors and therefore different sizes of micro gearwheels. Required tolerances for these components are in the same range as measurement accuracy $(\sim 1 \mu \mathrm{m})$. This is of special interest when production of micro planetary gears is in question because it requires highly accurate micro assembly and micro measurements. 


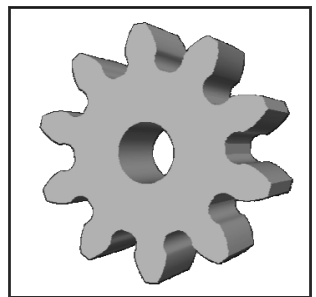

Fig. 15. Schematic of a $\mathrm{ZrO}_{2}$ micro gearwheel (outer diameter $1200 \mu \mathrm{m}$ ).

Besides small dimensions, micro-components are often required to have several functions at the same time. For that reason two-component CIM technology (2C-CIM) can be successfully applied in production of advanced ceramic micro-components (Piotter et al., 2008; Yin et al., 2008). This technology uses different combinations of ceramic materials thus providing the major advantage of the $2 \mathrm{C}$-CIM process: any assembly of micro-CIM parts after sintering is not necessary. The sintering rate control is crucial part of $2 \mathrm{C}-\mathrm{CIM}$ process. Both components must sinter at similar rates and similar positions in the sintering temperature to avoid delaminating. The sintering behavior can be adjusted by lowering the powder content in one mix thus affecting its green density and risking high porosity of the component. Also, a non-sintering composite phase can be added. When 2C-CIM process is in question, chosen materials must have compatible sintering characteristics. The feedstock components can be injected sequentially or simultaneously depending on the design and size of the contact area of both ceramic materials. In order to secure high compound strength, it is essential that injection processes are performed in a quick succession. Feedstocks that are being used must have comparable shrinkage rates during co-debinding and co-sintering. The shrinking behavior depends on the type of ceramic powder used and its particle size distribution as well as on the solid content of the feedstock. If the onsets of shrinkage of both components are comparable and thermal expansion coefficients are almost the same, then the defect-free material compounds can be achieved and high cooling stresses can be avoided.

As an illustration of 2C-CIM process, a schematic presentation of two-component shaft-gear wheel combination with fixed shaft-to-collar connection is given in Fig. 16. As a suitable material for gear wheel, zirconia is selected because of its sufficiently high toughness. The shaft is composed of alumina because of its hardness. Each of two chosen materials has a characteristic behavior during processing. Zirconia has a thermal expansion coefficient of $10-11 \times 10^{-6} / \mathrm{K}$ and therefore will show greater thermal expansion than alumina with a thermal expansion coefficient $7-8 \times 10^{-6} / \mathrm{K}$. The shrinkage behavior of the two components

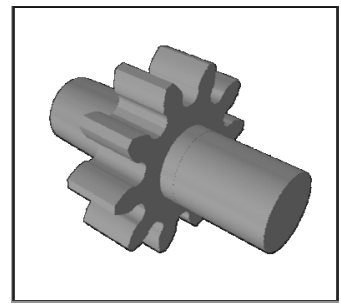

Fig. 16. Schematic of a 2C-CIM shaft-gear wheel combination (shaft: $\mathrm{Al}_{2} \mathrm{O}_{3}$; gear wheel: $\mathrm{ZrO}_{2}$ ). 
strongly depends on properties of selected zirconia and alumina powders. Since their sintering properties are affected by particle size, specific surface and additives, the shrinkage of both components should be adapted in such a way that dynamics of densification provide a shrink fit without cracking or destruction of the assembly. A different adaptation of parameters may lead to loosening of both components resulting in a formation of movable joint. Movable connections open new possibilities for 2C-CIM with a great reduction in mounting and assembly efforts and costs.

At the moment major growth areas in CIM are micro-CIM and 2C-CIM technologies (Fig. 17). Combination of the physical properties of the various materials is the key research activity when 2C-CIM technology is in question. Micro-CIM technology faces the challenge of developing suitable feedstock and high precision miniaturized mold cavities. Also, both technologies require computer modeling of molding, debinding and sintering in order to predict shape, size and reliability issues. Additionally, there are research activities ongoing to include higher functionality into micro-CIM components e.g. by the use of nano-sized powders.

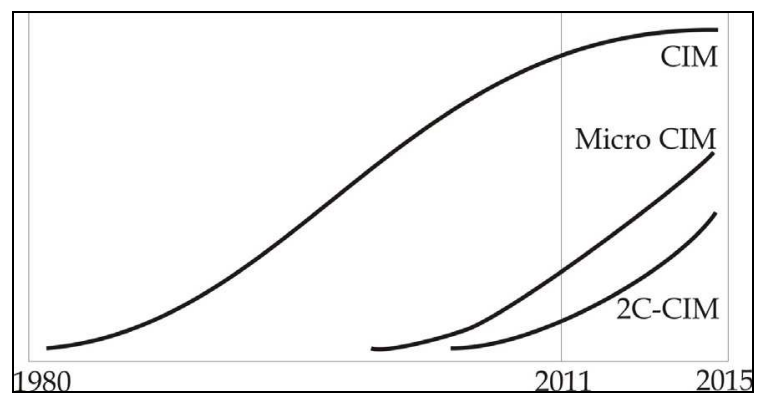

Fig. 17. Ceramic injection molding technology development.

\section{Conclusion}

In the recent years CIM technology has been accepted as one of the fundamental manufacturing techniques for mass production of ceramic components with complex geometries. Most commonly used CIM components are based on ferrite, piezoelectric and alumina ceramic powders. CIM components are widely used in automotive industry (mechanical parts), chemical applications (valves, membranes), medical applications (artificial bones), aerospace (mechanical parts, sensors and actuators), communications, oil and gas exploration (sensors, valves), etc. Advanced CIM technology, micro-CIM, offers microparts with structures in sub-millimetre range where materials like silicon and polymers rapidly reach their limits. Next step in micro-CIM technology is two-component micro-CIM that allows the production of multi-functional ceramic parts in just one processing step without any additional joining of the compound partners. Two-component injection molding allows one to combine materials with different properties, such as electrical conductivity/electrical insulation, high thermal conductivity/thermal insulation, or magnetic/non-magnetic properties. This opens new prospects for CIM technology and leads the way to new prospective market segments. 


\section{Acknowledgment}

Authors are grateful for the partial support of the Ministry of Education and Science of Republic of Serbia (contracts III45007 and III44003).

\section{References}

Gu, Y.W.; Li, T.; Li, Q.F.; Pook, S.F. Pook, \& Goh, C.W. (2008). Piezoelectric ceramics by powder processing. SIMTech technical reports, Volume 9, Number 4, (Oct-Dec 2008), pp. 189-194, Available from: http://www.simtech.astar.edu.sg/Research/ TechnicalReports/STR_V9_N4_CD_Version/STR_V9_N4_02_FTG.pdf

Hausnerova, B; Marcanikova, L.; Filip, P. \& Saha, P. (2011). Rheological Characterization of Powder Injection Moulding using Feedstock Based on Aluminium Oxide and Multicomponent Water-Soluble Polymer Binder. Proceedings of Recent Advances in Fluid Mechanics and Heat \& Mass Transfer, pp. 245-250, ISBN: 978-1-61804-026-8, Florence, Italy, August 23-25, 2011

Hwang, K. S. \& Hsieh, C. C. (2005). Injection-Molded Alumina Prepared with MgContaining Binders. Journal of the American Ceramic Society, 88 (9), (September 2005), pp. 2349-2353, DOI: 10.1111/j.1551-2916.2005.00370.x

Krauss, V.A.; Pires, E.N.; Klein, A.N. \& Fredel, M.C. (2005). Rheological Properties of Alumina Injection Feedstocks. Materials Research, Vol.8, No.2, (April-June 2005), pp. 187-189, ISSN 1516-1439

Liu, L; Loh, N.H.; Tay, B.Y.; Tor, S.B.; Yin, H.Q. \& Qu, X.H. (2011). Preparation and characterization of micro components fabricated by micro powder injection molding. Materials Characterization, 62 (6), (June 2011), pp. 615-620, DOI:10.1016/j.matchar.2011.04.009

Luo, J.S.; Yi, Z.Z.; Xiao, B.; Gao, Y.; Xie, Z.P.; Li, J.B. \& Huang, Y. (2006). Injection molding of ultra-fine zirconia (Y-TZP) powders. Journal of Ceramic Processing Research, 7(1), (2006), pp. 14-19, ISSN: 1229-9162

Pigram, A. J. \& Freer, R. (1994). The production of Mn-Zn ferrite ceramics by injection moulding. Journal of Materials Science, Vol. 29, No. 24, (January 1994), pp. 6420-6426, DOI: $10.1007 /$ BF00353998

Piotter, V.; Gietzelt, T. \& Merz, L. (2003). Micro powder-injection moulding of metals and ceramics. Sadhana, Vol. 28, Parts 1 \& 2, (February/April 2003), pp. 299-306, ISSN: 02562499

Piotter, V.; Plewa, K.; Prokop, J.; Ruh, A.; Ritzhaupt-Kleissl, H.J. \& Hausselt, J. (2008). Manufacturing of Versatile Ceramic or Metal Micro Components by Powder Injection Moulding. Proc.of the 4th Internat.Conf. on Multi-Material Micro Manufacture, pp. 69-72, ISBN 978-1-904445-76-0, Cardiff, GB, September 9-11, 2008, Dunbeath : Whittles Publ., 2008

Piotter, V.; Mueller, T.; Plewa, K.; Prokop, J.; Ritzhaupt-Kleissl, H.J. \& Hausselt J. (2010). Manufacturing of complex-shaped ceramic components by micropowder injection molding. The International Journal of Advanced Manufacturing Technology, 46 (1-4), (January 2010), pp. 131-134, DOI: 10.1007/s00170-009-2095-7

Rak, Z.S. (1999). New trends in powder injection moulding. Powder Metallurgy and Metal Ceramics, Volume 38, Numbers 3-4, (March 1999), pp. 126-132, DOI: 10.1007/BF02676037 
Rodríguez-Senín, E.; Várez, A.; Levenfeld, B.; Torralba, J. M. \& París,M. A. (2005). Processing of Mn-Zn ferrites using mould casting with acrylic thermosetting binder. Powder Metallurgy, 48(3), (September 2005), pp. 249-253, DOI:10.1179/174329005X64117

Skolyszewska, B.; Tokarz, W.; Przybylski, K. \& Kakol, Z. (2003). Preparation and magnetic properties of MgZn and MnZn ferrites. Physica C, 387(1-2), (May 2003), pp. 290-294, DOI: 10.1016/S0921-4534(03)00696-8

Stanimirović, I \& Stanimirović, Z. (2010). Piezoelectric Ceramic by Powder Injection Molding. Proceedings of $27^{\text {th }}$ International Conference on Microelectronics MIEL 2010, ISBN: 978-1-4244-7198-0, Niš, Republic of Serbia, May 16-19, 2010, IEEE

Stanimirović, Z \& Stanimirović, I. (2010). Injection Molded Mn-Zn Ferrite Ceramics. Proceedings of $27^{\text {th }}$ International Conference on Microelectronics MIEL 2010, ISBN: 978-1-4244-7198-0, Niš, Republic of Serbia, May 16-19, 2010, IEEE

Wang, S.; Li, J. F.; Wakabayashi, K.; Esashi, M. \& Watanabe, R. (1999). Lost Silicon Mold Process for PZT Microstructures. Adv. Mater., 11(10), (July 1999), pp. 873-876, DOI: 10.1002/(SICI)15214095(199907) 11:10<873::AID-ADMA873>3.0.CO;2-F

Wei, W.C.J.; Wu, R.Y. \& Ho, S.J. (2000). Effects of pressure parameters on alumina made by powder injection moulding. Journal of the European Ceramic Society, Volume 20, Issue 9, (August 2000), pp. 1301-1310, DOI: 10.1016/S0955-2219(99)00295-2

Yin, HQ.; Jia, CC. \& Qu, XH. (2008). Micro powder injection molding-large scale production technology for micro-sized components. Science in China Series E: Technological Sci., 51 (2), (Feb. 2008), pp. 121-126, DOI: 10.1007/s11431-008-0023-y

Zauner, R. (2006). Micro powder injection moulding. Microelectronic Engineering, Volume 83, Issues 4-9, (April-September 2006), pp. 1442-1444, DOI:10.1016/j.mee.2006.01.170

Zlatkov, B. S.; Griesmayer, E.; Loibl, H.; Aleksić, O. S.; Danninger, H.; Gierl, C. \& Lukić, L. S. (2008). Recent Advances in CIM Technology. Science of Sintering, 40(2), (2008), pp. 185-195, DOI:10.2298/SOS0802185Z

Zlatkov, B. S.; Mitrović, N.S.; Nikolić, M.V.; Marićić, A.M.; Danninger, H.; Aleksić, O. S. \& Halwax, E. (2010). Properties of MnZn ferrites prepared by powder injection molding technology. Materials Science and Engineering B, 175(3), (December 2010), pp. 217-222, DOI:10.1016/ j.mseb.2010.07.031 


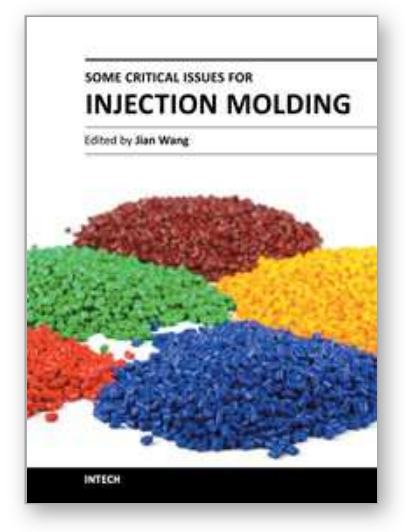

\author{
Some Critical Issues for Injection Molding \\ Edited by Dr. Jian Wang
}

ISBN 978-953-51-0297-7

Hard cover, 270 pages

Publisher InTech

Published online 23, March, 2012

Published in print edition March, 2012

This book is composed of different chapters which are related to the subject of injection molding and written by leading international academic experts in the field. It contains introduction on polymer PVT measurements and two main application areas of polymer PVT data in injection molding, optimization for injection molding process, Powder Injection Molding which comprises Ceramic Injection Molding and Metal Injection Molding, ans some special techniques or applications in injection molding. It provides some clear presentation of injection molding process and equipment to direct people in plastics manufacturing to solve problems and avoid costly errors. With useful, fundamental information for knowing and optimizing the injection molding operation, the readers could gain some working knowledge of the injection molding.

\title{
How to reference
}

In order to correctly reference this scholarly work, feel free to copy and paste the following:

Zdravko Stanimirović and Ivanka Stanimirović (2012). Ceramic Injection Molding, Some Critical Issues for Injection Molding, Dr. Jian Wang (Ed.), ISBN: 978-953-51-0297-7, InTech, Available from:

http://www.intechopen.com/books/some-critical-issues-for-injection-molding/ceramic-injection-molding

\section{INTECH}

open science | open minds

\section{InTech Europe}

University Campus STeP Ri

Slavka Krautzeka 83/A

51000 Rijeka, Croatia

Phone: +385 (51) 770447

Fax: +385 (51) 686166

www.intechopen.com

\section{InTech China}

Unit 405, Office Block, Hotel Equatorial Shanghai

No.65, Yan An Road (West), Shanghai, 200040, China

中国上海市延安西路65号上海国际贵都大饭店办公楼405单元

Phone: +86-21-62489820

Fax: $+86-21-62489821$ 
(C) 2012 The Author(s). Licensee IntechOpen. This is an open access article distributed under the terms of the Creative Commons Attribution 3.0 License, which permits unrestricted use, distribution, and reproduction in any medium, provided the original work is properly cited. 